\title{
Migration and other movements among the lower Paraná River valley wetlands, Argentina, and the south Brazil/Pantanal wetlands
}

\author{
PAULO DE TARSO ZUQUIM ANTAS
}

\section{Summary}

The southern portion of South America plays an important role for the conservation of many waterfowl and waders. Migratory movements were, till recently, known only for Arctic or Patagonian species. The only exception was the Southern Pochard Netta peposaca, with a west-east winter migration from the lower Paraná River valley to south Brazil coastal wetlands. The banding studies that have been conducted by the Centro de Pesquisas para a Conservação das Aves Silvestres (CEMAVE/IBAMA) since 1980, directly or through agreements with local organizations, showed more details of this migration, plus indications that other aquatic species such as Chilean Flamingo Phoenicopterus chilensis, other duck species, Neotropic Cormorant Phalacrocorax olivaceus and White-faced Ibis Plegadis chihi may follow the same pattern. A migration into the same area of the Pantanal population of the Wood Stork Mycteria americana was only recently discovered, and other species may also do likewise when the Pantanal is seasonally flooded. The studies of such bird migration or movements between the main South American wetlands are of great importance to understanding their conservation needs, especially when international cooperation among the countries plays a most important role. The region has been suffering human pressures of various types, from land reclamation for pasture and/or agriculture to the operation, in the last 30 years, of big hydroelectric dams which affect the natural flow of rivers or keep flood-plains under water. The impending construction of the Hidrovia Paraná/Paraguay, a large project for heavy river use as a main transportation route, may represent an enormous impact on such rich aquatic habitats, demanding immediate cooperation among the countries involved to mitigate negative effects on the environment. The impact may be similar to what happened in the Mississippi valley early this century. The westeast movements between the Paraná River valley and south Brazil are of special conservation interest, as a nationally threatened species (in Brazil) is involved (the Chilean Flamingo) as well as duck species targeted for the hunting season in the area.

O cone sul do continente sulamericano é um dos locais mais importantes, ao nível mundial, para as aves aquáticas. Estão ali localizados o Pantanal, o vale do Rio 
Paraná e seus banhados, bem como os ambientes aquáticos do estado do Rio Grande do Sul. Como em outros casos, essas áreas possuem ritmos estacionais marcados pelas cheias periódicas, com efeitos sobre as aves que habitam tais ambientes. Anteriormente só se conheciam as migrações de aves oriundas do Artico ou do extremo sul do continente, com exceção da migração de Netta peposaca entre a Argentina e o sul do Brasil. Os estudos, com anilhamento, de aves aquáticas foram iniciados pelo Centro de Pesquisas para Conservação de Aves Silvestres (CEMAVE/IBAMA) em 1980, diretamente ou com a participação de organizações locais através de convênios. Como resultado dos trabalhos, temos a confirmação de movimentos migratórios de Netta peposaca entre o baixo Rio Paraná e o litoral do Rio Grande do Sul, com dados para outras espécies de anatídeos sugestivos de movimentos semelhantes; a verificação de migração do Phoenicopterus chilensis, vindo da mesma região ou de áreas próximas como Mar Chiquita, em Córdoba, para o Parque Nacional da Lagoa do Peixe, litoral do Rio Grande do Sul, padrão que também pode ser seguido por algumas populações argentinas de Phalacrocorax olivaceus; os movimentos do Plegadis chihi a partir do vale do Rio Paraná para o Rio Grande do Sul e vice-versa, bem como para o Pantanal; e o importante movimento migratório da população de Mycteria americana do Pantanal para o vale do Rio Paraná e Rio Grande do Sul, provavelmente o mesmo movimento realizado por outras aves que abandonam total ou parcialmente o Pantanal na época de cheia (Novembro/Maio). Essa intensa movimentação de aves aquáticas ressalta a importância da conservação desses ambientes em uma escala continental, em um programa cooperativo entre o Brasil, Argentina, Uruguai e Paraguai. Tal programa é fundamental para o futuro dos grupos envolvidos, especialmente devido às intensas pressões humanas sobre tais ambientes, seja através da construção de hidroelétricas alterando o regime natural de cheias e vazantes ou inundando os baixios laterais dos rios, seja através da drenagem para agricultura ou pecuária. A existência de intenso movimento de leste para oeste, entre o Rio Grande do Sul e a Argentina é, também de grande interesse para a conservação, ou por envolver espécies com risco de extinção ao nível nacional (flamingo) seja para aves utilizadas nas temporadas de caça dos países envolvidos (patos). A preparação da Hidrovia Paraná/Paraguai pode significar um impacto negativo importante sobre os ambientes dos quais essas aves dependem, como foi, nos Estados Unidos, a transformação do Rio Mississipi em corredor de transporte fluvial, com efeitos deletérios sobre comunidades associadas ao regime natural de cheias dos rios.

\section{Introduction}

The wetlands of the central/southern portion of South America are among the world's largest, both in size and in terms of their importance for aquatic bird species. The Paraguay River, the most important tributary of the Paraná River, is almost a continuous wetland after its descent from the Central Brazilian Plateau highlands, forming the Pantanal in the upper valley and feeding a big floodplain south of it. The Paraná is a river with rapid waters in its Brazilian portion, becoming a slow-water river with a large flood-plain after it enters Argentina and is joined by the Paraguay River. Forming the southernmost part of Brazil, the state of Rio Grande do Sul is not affected by major rivers, although its wetlands are similar to those found in Argentina and Uruguay. 
A group of at least 86 waterbird species depend on such wetland habitats, including species that migrate from the Arctic or Patagonia to the area every year, a better known assemblage than those undertaking the recently discovered migration between the Pantanal, lower Paraná River valley and south Brazil wetlands (Table 1). However, most of the strategies, movements or even true migrations are still unknown. Considering the marked seasonal variation in water levels in the Pantanal, the lower Paraná river valley and south Brazil, a larger variety of species than already known may use migration as a strategy to survive such changes and their associated variations in food supply. The presence of other species in these wetlands may simply reflect their nomadism, as they search for better feeding conditions during severe droughts.

Among the waterfowl, there are three classes of bird treated under Brazilian legislation. They are: (1) migratory species, considered under the Convention on Nature Protection and Wildlife Preservation in the Western Hemisphere, signed and ratified by American countries during the 1940s (the convention stimulates the parties to protect birds migrating across borders, treating them as a shared natural resource); (2) colonial birds, which have protection under Brazilian legislation for faunal conservation (Lei 5.197/67), and specifically their colonies; (3) game species, which are also treated under the faunal conservation law.

The federal body with authority for the implementation of the law and other measures is the Instituto Brasileiro do Meio Ambiente e dos Recursos Naturais Renováveis (IBAMA), created in January 1990. Within IBAMA lies the Centro de Pesquisas para a Conservação das Aves Silvestres (CEMAVE), set up in 1977; its main task is the organization of the national bird-banding system, gathering the basic biological data necessary for the establishment of sounding bird-based conservation policies at the federal level.

The bird-banding centre, whose headquarters are in Brasília, receives information from all birds banded in the country by the 340 authorized banders. All bands used in Brazil have P.O. Box 34, Brasilia, as the return address. From each recovered band the centre collects the date and place of recovery. Information is kept within CEMAVE's files and is also sent to the bander. From 1980 onwards, around 145,000 birds were banded in Brazil, with an overall recovery rate of $1.5 \%$.

Besides its banding branch, CEMAVE also conducts fieldwork, both directly or under agreement with other organizations, to collect data on the three groups of birds mentioned above. For waterfowl, both the Pantanal and south Brazil are of high priority for such work. Although the migratory strategies of many species are still unknown, we have already information on some species's movements.

\section{Results}

\section{Ducks}

The Rosy-billed Pochard Netta peposaca is the preferred duck quarry of hunters in south Brazil. Earlier studies (Olrog 1968), based on 173 banded ducks and 20 recovered bands, showed movements of this species from Argentina's northwestern province of Santiago del Estero into south Brazil, followed by a pre- 
Table 1. Aquatic birds occurring in the wetlands of south Brazil (SB), Pantanal (P) and lower Paraná River valley (Argentina) (LP). Sources: Belton (1984), Narosky and Yzurieta (1987), plus personal observations in the Pantanal and Rio Grande do Sul state

\begin{tabular}{|c|c|c|c|c|}
\hline \multirow[t]{2}{*}{ Species } & \multicolumn{3}{|c|}{ Range } & \multirow[b]{2}{*}{ Migration } \\
\hline & SB & 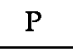 & LP & \\
\hline Rollandia rolland & $\mathrm{x}$ & - & $x$ & Unknown \\
\hline Podiceps major & $x$ & - & $x$ & ", \\
\hline Podiceps dominicus & $x$ & $x$ & $x$ & $" \prime$ \\
\hline Podilymbus podiceps & $x$ & $\mathrm{x}$ & $\mathrm{x}$ & , \\
\hline Phalacrocorax olivaceus & $x$ & $x$ & $x$ & Movement from LP to SB \\
\hline Anhinga anhinga & rare & $\mathrm{X}$ & $x$ & Unknown \\
\hline Botaurus pinnatus & rare & $?$ & $\mathrm{X}$ & ", \\
\hline Tigrisoma lineatum & $\mathrm{x}$ & $\mathrm{X}$ & $x$ & $"$ \\
\hline Nycticorax nycticorax & $\mathrm{x}$ & $\mathrm{x}$ & $\mathrm{x}$ & ", \\
\hline Cochlearius cochlearius & $\mathrm{x}$ & $\mathrm{X}$ & $\mathrm{x}$ & ", \\
\hline Bubulcus ibis & $\mathrm{x}$ & $\mathrm{X}$ & $x$ & $"$, \\
\hline Butorides striatus & $x$ & $x$ & $x$ & $"$ \\
\hline Egretta thula & $\mathrm{X}$ & $x$ & $x$ & , \\
\hline Casmerodius albus & $x$ & $x$ & $x$ & " \\
\hline Ardea cocoi & $\mathrm{x}$ & $\mathrm{x}$ & $\mathrm{X}$ & ," \\
\hline Mycteria americana & $x$ & $x$ & $x$ & $P$ to $L P / S B$ \\
\hline Ciconia maguari & $x$ & $x$ & $x$ & Possibly LP to $P$ \\
\hline Jabiru mycteria & rare & $\mathrm{x}$ & $x$ & Unknown \\
\hline Harpiprion caerulescens & rare & $x$ & $x$ & " \\
\hline Theristicus caudatus & $\mathrm{x}$ & $x$ & $x$ & " \\
\hline Phimosus infuscatus & $\mathrm{X}$ & $x$ & $x$ & Possibly LP to $P$ \\
\hline Plegadis chihi & $\mathrm{x}$ & $x$ & $x$ & $\begin{array}{l}\text { Migration LP to } P \\
\text { Movements SB/LP }\end{array}$ \\
\hline Platalea ajaja & $\mathrm{x}$ & $x$ & $\mathrm{x}$ & Unknown \\
\hline Phoenicopterus chilensis & $x$ & - & $x$ & Migration LP to SB \\
\hline Chauna torquata & $\mathrm{x}$ & $x$ & $x$ & Unknown \\
\hline Dendrocygna bicolor & $\mathrm{x}$ & $\mathrm{x}$ & $x$ & Movements SB/LP \\
\hline Dendrocygna viduata & $\mathrm{x}$ & $x$ & $x$ & Unknown \\
\hline Dendrocygna autumnalis & rare & $x$ & $x$ & " \\
\hline Cygnus melanocoryphus & $\mathrm{x}$ & - & $\mathrm{X}$ & $n$ \\
\hline Coscoroba coscoroba & $\mathrm{x}$ & - & $x$ & $" \prime$ \\
\hline Cairina moschata & rare & $\mathrm{X}$ & $\mathrm{x}$ & ", \\
\hline Sarkidiornis melanotos & rare & $x$ & $x$ & " \\
\hline Amazonetta brasiliensis & $\mathrm{X}$ & $\mathrm{X}$ & $x$ & Resident \\
\hline Anas leucophrys & $\mathrm{X}$ & rare & $\mathrm{x}$ & Unknown \\
\hline Anas sibilatrix & rare & - & $x$ & $n$ \\
\hline Anas flavirostris & $\mathrm{X}$ & - & $x$ & r \\
\hline Anas georgica & $\mathrm{X}$ & - & $x$ & Movements SB/LP \\
\hline Anas bahamensis & rare & - & $x$ & Unknown \\
\hline Anas versicolor & $x$ & - & $\mathrm{x}$ & ", \\
\hline Anas cyanoptera & rare & - & $x$ & $n$ \\
\hline Anas platalea & $x$ & - & $x$ & " \\
\hline Netta peposaca & $x$ & - & $x$ & Migration SB/LP \\
\hline Heteronetta atricapilla & rare & - & $x$ & Unknown \\
\hline Oxyura dominica & $\mathrm{X}$ & $x$ & $\mathrm{X}$ & ", \\
\hline Oxyura vittata & rare & - & $x$ & " \\
\hline Rostrhamus sociabilis & $x$ & $x$ & $x$ & Possibly LP/SB to Pantanal \\
\hline Busarellus nigricollis & - & $x$ & $\mathrm{x}$ & Unknown \\
\hline Pandion haliaetus & rare & $\mathrm{x}$ & $\mathrm{x}$ & North America migrant \\
\hline Aramus guarauna & $X$ & $x$ & $x$ & Unknown \\
\hline Rallus sanguinolentus & $x$ & - & $x$ & ", \\
\hline
\end{tabular}


Table 1 -continued.

\begin{tabular}{|c|c|c|c|c|}
\hline \multirow[t]{2}{*}{ Species } & \multicolumn{3}{|c|}{ Range } & \multirow[b]{2}{*}{ Migration } \\
\hline & SB & $P$ & LP & \\
\hline Rallus maculatus & rare & ? & $x$ & Unknown \\
\hline Aramides cajanea & $x$ & $x$ & $x$ & " \\
\hline Fulica armillata & $x$ & - & $x$ & Movements LP/SB \\
\hline Fulica leucoptera & $x$ & - & $x$ & , \\
\hline Fulica rufifrons & $x$ & - & $x$ & Unknown \\
\hline Gallinula chloropus & $x$ & $\mathrm{x}$ & $x$ & ", \\
\hline Porphyrula martinica & $\mathrm{x}$ & rare & $x$ & ", \\
\hline Porphyrops melanops & $\mathrm{x}$ & - & $x$ & ", \\
\hline Jacana jacana & $\mathrm{x}$ & $x$ & $x$ & , \\
\hline Nycticryphes semicollaris & rare & - & $x$ & ," \\
\hline Himantopus himantopus & $\mathrm{x}$ & $\mathrm{x}$ & $x$ & ," \\
\hline Vanellus chilensis & $x$ & $\mathrm{x}$ & $x$ & ", \\
\hline Pluvialis squatarola & $\mathrm{x}$ & rare & $x$ & North American migrant \\
\hline Pluvialis dominicana & $x$ & $\mathrm{X}$ & $x$ & , \\
\hline Oreophilus ruficollis & rare & - & $\mathrm{x}$ & South American migrant \\
\hline Charadrius falklandicus & $\mathrm{X}$ & - & $\mathrm{x}$ & ", \\
\hline Charadrius semipalmatus & $x$ & $?$ & $x$ & North American migrant \\
\hline Charadrius collaris & $\mathrm{x}$ & $\mathrm{X}$ & $\mathrm{x}$ & Unknown \\
\hline Zonibyx modestus & $x$ & - & $\mathrm{x}$ & South American migrant \\
\hline Tringa melanoleuca & $x$ & $x$ & $x$ & North American migrant \\
\hline Tringa flavipes & $x$ & $x$ & $x$ & ", \\
\hline Tringa solitaria & $x$ & $x$ & $x$ & " \\
\hline Tryngites subruficollis & $x$ & $x$ & $x$ & ", \\
\hline Calidris melanotos & $x$ & $x$ & $x$ & $"$ \\
\hline Calidris fuscicollis & $\mathrm{x}$ & $?$ & $\mathrm{X}$ & $"$ \\
\hline Numenius borealis & - & $x$ & $\mathrm{x}$ & ", \\
\hline Bartramia longicauda & rare & $\mathrm{x}$ & $\mathrm{X}$ & ", \\
\hline Gallinago gallinago & $\mathrm{X}$ & $\mathrm{x}$ & $\mathrm{X}$ & Unknown \\
\hline Gelochelidon nilotica & $x$ & - & $x$ & ", \\
\hline Sterna trudeaui & $\mathrm{X}$ & - & $\mathrm{X}$ & $"$ \\
\hline Phaetusa simplex & rare & $X$ & $x$ & ", \\
\hline Sterna superciliaris & $x$ & $X$ & $X$ & ", \\
\hline Rynchops nigra & $\mathrm{x}$ & $\mathrm{X}$ & $X$ & ", \\
\hline Ceryle torquata & $\mathrm{x}$ & $x$ & $x$ & ", \\
\hline Chloroceryle amazona & $x$ & $x$ & $x$ & ", \\
\hline Chloroceryle americana & $x$ & $x$ & $\mathrm{x}$ & ", \\
\hline
\end{tabular}

breeding migration to the lower Paraná River valley, the main breeding area of this population. Olrog's proposed migration model considered a three-step migration, from the breeding grounds in the Paraná valley to a moulting area in north-west Argentina and thence to winter quarters in south Brazil. Based on 2,689 banded Rosy-billed Pochard from 1980 until 1989 and a $6.3 \%$ recovery rate, it seems that the pochards from the Paraná river basin migrate after breeding mainly to coastal south Brazil, eliminating the north-west stopover (Antas et al. 1990). They use the central wetlands of Rio Grande do Sul state as the migratory pathway.

Analysis of the band recoveries from the Fulvous Whistling-duck Dendrocygna bicolor, based on 1,585 banded ducks from 1979 to 1989 and a $3.2 \%$ recovery rate, also showed a strong movement from the Rio Grande do Sul coastal wet- 
lands into the Paraná river valley, in Argentina, for the breeding season. However, there is currently no evidence of a true migration, as the birds did not reappear in south Brazil after nesting, but remained in the valley wetlands. Marked birds have been recovered in Brazil again two or three years later, suggesting this species may move in response to local conditions (droughts or catastrophic floods probably being the major factors), not truly migrating (Nascimento et al. 1990). The central Rio Grande do Sul wetlands are also the migratory flyway to reach the Argentinian breeding grounds.

The Yellow-billed Pintail Anas georgica is another duck from the south Brazil wetlands with some migratory movements into the Paraná River valley. Silva (1987) reported a banding recovery in the western portion of the Andes, in Chile, and suggested a movement east-west in this species. Analysis of Yellowbilled Pintails banded in Argentina, both in the Paraná river valley and in northwest Argentina, show movements into south Brazil or to south-central Argentina and coastal Buenos Aires province (Olrog 1962, 1968, 1971, 1973), indicating that birds using the Paraná river valley and the north-western wetlands come from various regions. The Brazilian population has its main breeding grounds in the coastal and upland regions of Rio Grande do Sul state (Belton 1984; pers. obs.). The Brazilian band recoveries analysis also reinforces this point (Antas and Nascimento 1991). Large concentrations of pintails (up to thousands) - possibly from a vast area of southern South America - occur near the border with Uruguay, in Lagoa Mirim, for flight-feather moult in January, February and March (Silva 1987). The population, however, is dominated by birds of Brazilian origin, as indicated by the few recoveries from outside Brazil. Again the central Rio Grande do Sul wetlands are the migratory flyway for birds flying back and forth.

There is less evidence of true migration from band recoveries of other species such as Black-headed Duck Heteronetta atricapilla, with one bird banded in northwest Argentina and recovered in south Brazil (Olrog 1975) and Silver Teal Anas versicolor, with a south Brazil recovery of a bird banded in the Paraná River valley (Olrog 1971) and another banded in Brazil and found later in Córdoba province, central Argentina (CEMAVE unpublished data).

\section{The Chilean Flamingo and the Neotropic Cormorant}

The Chilean Flamingo Phoenicopterus chilensis has a breeding population in the salt lagoons of Santa Fe, Buenos Aires and Córdoba provinces (Scott and Carbonell 1986), most notably the Mar Chiquita salt lagoon, in Córdoba, which comprises the main breeding area (Nores and Yzurieta 1980, E. Bucher pers. comm.). After the breeding season the flamingos move to unknown areas, some going eastwards towards the coastal salt/brackish lagoons of south Brazil, Uruguay and Argentina. The Parque Nacional da Lagoa do Peixe, in coastal Rio Grande do Sul, is the only site where Chilean Flamingos occur in Brazil yearround. Despite this, the adult flamingo population of up to 450 individuals leave Lagoa do Peixe before the breeding season and return afterwards with the young of the year. The lack of known breeding colonies between Rio Grande do Sul state and the east margin of the Paraná River suggests that southern Brazil flamingos might breed on the west bank of the Paraná River in Argentina. 
Neotropic Cormorant Phalacrocorax olivaceus movements are more difficult to understand, as it has breeding colonies both in southern Brazil and in Argentina. However, nestlings banded at a Santiago del Estero colony (Argentina) have been recovered both in the Paraná River valley and in south Brazil, indicating movements similar to the above-mentioned duck species.

\section{The White-faced Ibis}

The White-faced Ibis Plegadis chihi occurs in all three regions. It is truly migratory in the Pantanal, where it is observed from late May until October (pers. obs.) or April until December (Cintra and Yamashita 1990). There is no breeding in the Pantanal and these ibises must immigrate from their Argentine colonies. A nestling banded in Santa Fe province, Argentina, was found in August 1968 near Corumbá (Olrog 1971), confirming this movement. However, it is worth noting that other nestlings of the same colony were found in various parts of southern Brazil. The White-faced Ibis is found year-round in Rio Grande do Sul's wetlands. Ibises banded in Brazil have also been recovered on the lower Paraná River (CEMAVE unpublished data), showing movements between both areas. Such movements, however, do not exhibit a truly seasonal migration such as birds of this species show between Argentina and the Pantanal.

\section{Migrations and movements of birds from the Pantanal}

Even less known are the movements and migrations of birds from the Pantanal. The Pantanal itself is a $150,000 \mathrm{~km}^{2}$ wetland complex, formed by the upper Paraguay River and its northern tributaries. It is a flat area, filled by sandy quaternary sediments washed mainly from the Central Brazilian Plateau. These rivers and the Paraguay inundate the flood-plain during the rainy season (October/December until April/May, depending on the river basin). The Pantanal is a complex with various types of wetland and dry-terrain forest, cerrado and other forest types. In the south-central portion a large number of small salt/ brackish closed lagoons occur. The lowland is almost flat and natural drainage is very slow, leaving the region covered with water (from 0.5 to $5 \mathrm{~m}$ ) for long periods of time. The Pantanal harbours the main breeding colonies of many fish-eating birds in South America. They feed on fish trapped in pools that form as the water level drops.

Besides the White-faced Ibis, the Wood Stork Mycteria americana also migrates from the Pantanal into the Paraná River valley and, also, into the south Brazil wetlands. The Wood Stork breeds in the Pantanal but not in Rio Grande do Sul (Belton 1984), and may have small colonies in Argentina. Nestlings have been banded in the northern (Yamashita and Valle 1987) or central Pantanal (CEMAVE unpublished data). The species appears in November and remains until April (Belton 1984; pers. obs.). Banded Wood Storks were found in January and February in Argentina and Rio Grande do Sul during the rainy season in central Brazil, when the species is absent from the Pantanal.

The Maguari Stork Ciconia maguari is also seasonal in the Pantanal (Cintra and Yamashita 1990; pers. obs.). During terrestrial surveys of the central-western Pantanal in July/August and October from 1988 to 1990, all Maguari Storks were 
in full adult plumage (CEMAVE unpublished data). There are few confirmed breeding records in the Pantanal, the Paraná valley and/or Rio Grande do Sul being the most probable source of the Pantanal's Maguari Storks.

Another colonial nester seasonally abundant in the Pantanal is the Roseate Spoonbill Platalea ajaja. The area has the most important colonies of this species in South America. Its movements are unknown, but it disappears between January and April from the northern Pantanal (Cintra and Yamashita 1990). It may follow the Wood Stork movement, a species with which the spoonbill is associated both in feeding and in breeding areas.

The Snail Kite Rostrhamus sociabilis is present in Pantanal from April to October (Cintra and Yamashita 1990). In the central Pantanal, large flocks (40-80) have been observed moving south in late October (pers. obs.). Snail Kites do not breed in the Pantanal; the most probable origin of the Pantanal population is Argentina or Rio Grande do Sul.

\section{Threats to the wetlands}

The current information shows an important linkage between the Pantanal, the lower Paraná River valley and the Rio Grande do Sul wetlands for waterfowl migration. The Paraná River valley and adjacent wetlands play a fundamental role in the conservation of many waterfowl from both Brazilian areas. The Argentine wetlands are used mainly for breeding, by ducks from Rio Grande do Sul or White-faced Ibis from the Pantanal; at the same time, the region is the most probable non-breeding quarter for waterfowl leaving the Pantanal during the flood season.

There is an urgent need for fieldwork on an international scale and a coordinated effort among the different countries involved to increase our understanding of the importance of this region and to investigate other species's movements or migration strategies. The design of conservation policies for migratory species within the region requires further fieldwork in order to gather the basic information to develop proper regional migratory species conservation plans. The Paraná River area has a tremendous significance for aquatic species and wetland conservation, holding a cluster of 14 wetlands sites of international importance listed in Scott and Carbonell (1986).

However, the natural system has been severely affected by large hydroelectric dams constructed during the last 30 years upstream in the Paraná River basin. There are plans to build hydroelectric power plants in the Paraguay River basin on the Central Brazilian Plateau, and also plans to use the Paraguay mainstream for heavy material transportation, a project known as the Hidrovia Paraná/Paraguay. If there is no proper discussion of the environmental impacts of the Hidrovia and implementation of measures to mitigate them, its effects could be similar to those already felt in the Mississippi valley earlier this century as result of a similar project. The Hidrovia may damage the whole seasonal flood system and river water speed, affecting both local resident species as well as the migrants depending on the riverine wetlands.

Although the southern Brazilian and the Paraná River wetlands in Argentina are similar the composition of their flora and fauna, there is an important difference in terms of water supply. The Rio Grande do Sul wetlands are completely 
dependent on local rainfall, and are severely affected by droughts. The lower Paraná River wetlands, although also affected by local rain, are more linked with the upper river water supply, with consequently less vulnerability to local droughts. However, when man begins to control the upper river level through dams, two artificial effects may occur in the wetlands. During below-average rainfall years within the basin, the water will be retained in the reservoirs, decreasing the river level and desiccating wetlands. On the other hand, during above-average rainfall years, too much water will be released into the river at once, raising its level suddenly, washing out its margins and keeping wetlands under artificially high water levels.

Another important human activity affecting the wetlands at a local scale is agriculture and cattle-grazing. For these activities, wetlands are reclaimed both through drainage and/or polder construction, with considerable damage to the ecosystem.

\section{Acknowledgements}

The presentation of this paper during the IV Neotropical Ornithological Congress was possible thanks to a grant from the ICBP-PACS and WWF-US. This work has been continuously funded by the Instituto Brasileiro do Meio Ambiente e dos Recursos Naturais Renováveis.

\section{References}

Antas, P. T. Z., Nascimento, J. L. X., Silva, F. and Scherer, S. B. (1990) Migração de Netta peposaca entre o sul do Brasil e a Argentina. P.24 in Resumos VI Encontro Nacional de Anilhadores de Aves. Rio Grande do Sul: Universidade Católica de Pelotas.

Antas, P. T. Z. and Nascimento, J. L. X. (1991) Movimentação e situação atual de Anas georgica no sul do Brasil. Resumenes del IV Congreso de Ornitología Neotropical, 3-9 de Noviembre, 1991, Quito, Ecuador (summary 149).

Belton, W. (1984) Birds of Rio Grande do Sul, Brazil. 1: Rheidae through Furnariidae. Bull. Amer. Mus. Nat. Hist. 178: 369-636.

Cintra, R. and Yamashita, C. (1990) Habitats, abundância e ocorrência das espécies de aves do Pantanal de Poconé, Mato Grosso, Brasil. Pap. Avuls. Dep. Zool. São Paulo 37: 1-21.

Narosky, T. and Yzurieta, D. (1987) Guia para la identificación de las aves de Argentina y Uruguay. Buenos Aires, Argentina: Asociación Ornitológica del Plata.

Nascimento, J. L. X., Antas, P. T. Z., Silva, F. and Scherer, S. B. (1990) Movimentação de Dendrocygna bicolor entre o Rio Grande do Sul e Argentina. Pp.25-26 in Resumos, VI Encontro Nacional de Anilhadores de Aves. Rio Grande do Sul: Universidade Católica de Pelotas.

Nores, M. and Yzurieta, D. (1980) Aves de ambientes acuáticos de Córdoba y centro da Argentina. Córdoba, Argentina: Secretaria de Agricultura y Ganadería.

Olrog, C. C. (1962) El anillado de aves en Argentina, 1961-1962. Segundo Informe. Neotropica (Supl.) 8: I-VIII.

Olrog, C. C. (1968) El anillado de aves en Argentina, 1964-1966. Quinto Informe. Neotropica 14: 17-22.

Olrog, C. C. (1971) El anillado de aves en Argentina, 1961-1971. Séptimo Informe. Neotropica 17: 97-100. 
Olrog, C. C. (1973) El anillado de aves en Argentina, 1961-1974. Octavo Informe. Neotropica 19: 69-72.

Olrog, C. C. (1975) El anillado de aves en Argentina, 1961-1974. Noveno Informe. Neotropica 21: 17-19.

Scott, D. and Carbonell, M. (1986) A directory of Neotropical wetlands. Cambridge, U.K., and Slimbridge, U.K.: International Union for Conservation of Nature and Natural Resources, and International Waterfowl and Wetlands Research Bureau.

Silva, F. (1987) Movimentos de dispersão da Marreca-Parda (Anas georgica): recuperações e recapturas. Pp.211-212 in Anais do II Encontro Nacional de Anilhadores de Aves. Rio de Janeiro: Universidade Federal do Rio de Janeiro.

Yamashita, C. and Valle, M. P. (1987) Sobre o anilhamento e migração de Mycteria americana no Pantanal. Pp.196-197 in Anais do II Encontro Nacional de Anilhadores de Aves. Rio de Janeiro: Universidade Federal do Rio de Janeiro.

PAULO DE TARSO ZUQUIM ANTAS

CEMAVE/IBAMA, Caixa Postal o4/034, 70312-97o Brasilia D.F., Brazil. 